\title{
Immigration and emigration of a pelagic fish assemblage to seamounts in the Gulf of California related to water mass movements using satellite imagery
}

\author{
A. P. Klimley*, S. B. Butler \\ Mar. Biol. Res. Div. (A-002) and Grad. Dept (A-008), Scripps Institution of Oceanography, University of California, San Diego, \\ La Jolla, California 92093, USA
}

\begin{abstract}
The appearance of an assemblage of 11 planktivorous and predatory fishes at El Bajo Gorda seamount within the Gulf of California in May 1981 coincided with an increase in surface water temperature and chlorophyll concentration. The assemblage may have either concentrated at the seamount from the surrounding pelagic environment or immigrated from south of the Gulf of California. At this time the fall to early spring current flow southeastward toward the Gulf of Tehuantepec reverses to the spring to summer flow northeastward along the mainland into the Gulf to California. One assemblage member, the scalloped hammerhead shark Sphyma lewini, was monitored as an indicator of assemblage movements in response to water mass changes. The occurrences of 18 individuals tagged with individually recognizable transmitters were recorded over a 10 d period in July and August 1981 by 2 microprocessor monitors deployed at El Bajo Espiritu Santo seamount. Shark returns diminished as a mass of upwelled cold water, originating in the Bay of La Paz, moved over that seamount. The return rate then increased on a single day coincident with the incursion of a warm water mass before the rate decreased as this water mass cooled.
\end{abstract}

\section{INTRODUCTION}

Single species of fishes such as the albacore Thunnus alalunga are associated with hydrographic fronts. Albacore tagged with ultrasonic beacons remained near fronts mapped from in situ measurements of sea surface temperatures and chlorophyll pigment concentrations (Laurs et al. 1977). Large albacore catches were related using satellite images to the intrusion of an oceanic water mass with warm temperatures and low phytoplankton pigment concentrations into cooler coastal water characterized by lower temperatures and higher pigment concentrations (Laurs et al. 1984). The movements of a multispecies assemblage, on the other hand, have not yet been related to water mass movements.

During a field study of the social behavior of the scalloped hammerhead shark Sphyrna lewini, we

\footnotetext{
- Present address: Bodega Marine Laboratory, University of California, Davis, PO Box 247, Bodega Bay, California 94923, USA
}

found many pelagic species to co-occur with this species during daytime at seamounts and offshore islands in the Gulf of California. Members of this assemblage included planktivores such as the green jack Caranx caballus, gafftopsail pompano Trachinotus rhodopus, manta Manta hamiltoni, and whale shark Rhincodon typus. These species aggregated at the seamount to feed on high concentrations of zooplankton available there. Large predators such as the snappers Lutjanus aratus and Lutjanus peru and the scalloped hammerhead shark were also members of this assemblage. In this report we describe those oceanographic conditions which must be present for this assemblage to immigrate to 2 seamounts within the Gulf of California.

\section{METHODS}

We recorded the presence of members of a pelagic assemblage of fishes at $\mathrm{El}$ Bajo Gorda (EBG)

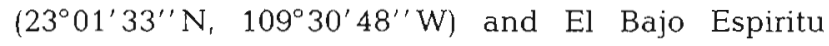




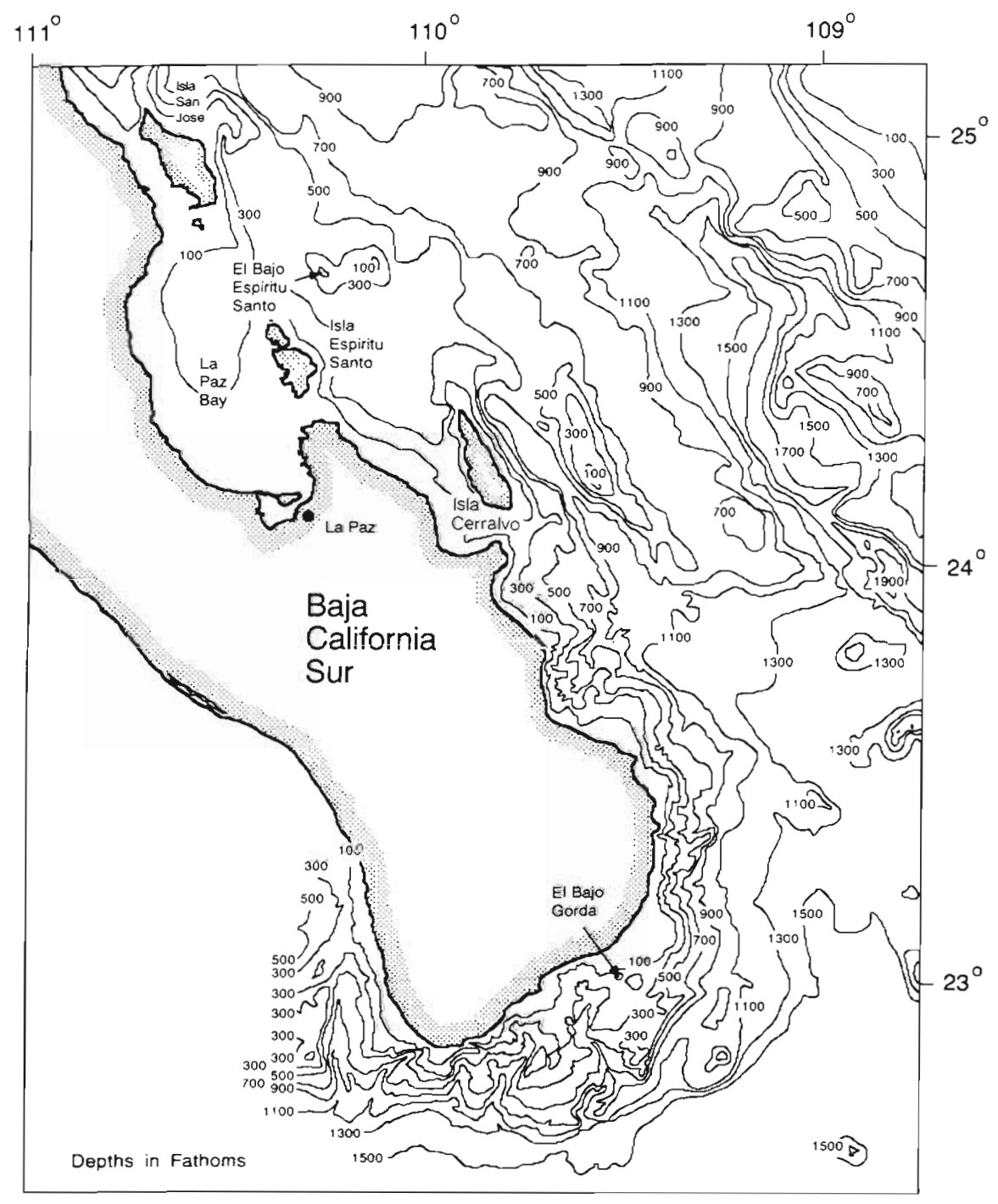

Fig. 1. Submarine topography of the Gulf of California. (Redrawn from Fisher et al. 1964)

Santo seamounts (EBES) $\left(24^{\circ} 41^{\prime} \mathrm{N}, 110^{\circ} 16^{\prime} \mathrm{W}\right)$ in the lower Gulf of California (Fig, 1) and related the occurrence of assemblage members to water mass changes. At EBG we searched for members on 6-7 and 13-14 May 1981 by drifting repeatedly over the $0.8 \mathrm{~km}^{2}$ area of EBG while free and SCUBA diving. Fishes were identified from both in situ observations and video records. At EBES, we recorded the occurrence of 18 individuals of one assemblage member, the scalloped hammerhead shark, over a $10 \mathrm{~d}$ period from 22 to 31 July 1986. Sharks were tagged with individually recognizable transmitters (MT-1, Ultrasonic Telemetry Systems), and shark arrivals and departures from EBES recorded with 2 microprocessor-based monitors (MM32, Ultrasonic Telemetry Systems) deployed at the seamount. The combined ranges of the monitores covered a $1 \mathrm{~km}^{2}$ area. The scheme for beacon recognition by the monitors, their deployment, and ranges are described in Klimley et al. (in press).
Sea surface temperature and chlorophyll concentration at EBG at the time of each visit were determined from NOAA 6 AVHRR (Advanced Very High Resolution Radiometer) and Nimbus 7 CZCS (Coastal Zone Color Scanner) satellite images. Although those images simultaneous with our visits to EBG were unusable because early morning cloud cover obscured part of the sea surface, temperature images on 5 and 12 May and phytoplankton pigment images on 5 and 10 May were usable. Those AVHRR images taken on afternoon passes of the NOAA 6 satellite on 5,7,9, and 12 May were separated by less than $1 \mathrm{~h}$; however, the 8 May image was taken on a morning pass (Table 1). It is possible that temperatures recorded in that image are slightly cooler than temperatures recorded in the afternoon images due to nocturnal cooling. The Nimbus 6 images were obtained from midday passes separated by only $10 \mathrm{~min}$ (Table 2), and for this reason, the confounding effect of a diel variation in phytoplankton distribution was minimal. 
Table 1. Dates, pass times, sea surface temperatures for El Bajo Gorda (EBG) and Espiritu Santo (EBES) at pixel P, and mean and standard deviation for $3 \times 3$ pixel matrix centered at $P$ for NOAA 6 AVHRR satellite images

\begin{tabular}{|c|c|c|c|c|c|}
\hline \multirow[t]{2}{*}{ Date } & \multirow[t]{2}{*}{ Time (h) } & \multirow[t]{2}{*}{ Loc. } & \multirow{2}{*}{$\begin{array}{c}\mathrm{P} \\
\left({ }^{\circ} \mathrm{C}\right)\end{array}$} & \multicolumn{2}{|c|}{ Pixel matrix } \\
\hline & & & & Mean $\left({ }^{\circ} \mathrm{C}\right)$ & $\operatorname{SD}\left({ }^{\circ} \mathrm{C}\right)$ \\
\hline 5 May 1981 & $19: 29$ & $E B G$ & 19.52 & 19.54 & 0.16 \\
\hline 7 May 1981 & $20: 24$ & $E B G$ & 18.21 & 18.27 & 0.11 \\
\hline 8 May 1981 & $08: 23$ & $\mathrm{EBG}$ & 19.04 & 19.04 & 0.13 \\
\hline 9 May 1981 & $19: 39$ & $\mathrm{EBG}$ & 19.78 & 19.78 & 0.10 \\
\hline 12 May 1981 & $20: 10$ & $\mathrm{EBG}$ & 20.03 & 20.06 & 0.07 \\
\hline 22 Jul 1986 & $14: 38$ & EBES & 28.63 & 28.62 & 0.33 \\
\hline 23 Jul 1986 & $14: 28$ & EBES & 19.15 & 19.14 & 0.09 \\
\hline 24 Jul 1986 & $15: 57$ & EBES & 28.31 & 28.24 & 0.09 \\
\hline 26 Jul 1986 & $15: 36$ & EBES & 26.93 & 26.92 & 0.09 \\
\hline 27 Jul 1986 & $15: 26$ & EBES & 28.11 & 28.10 & 0.09 \\
\hline 28 Jul 1986 & $15: 15$ & EBES & 28.63 & 28.71 & 0.08 \\
\hline 29 Jul 1986 & $15: 04$ & EBES & 30.54 & 30.52 & 0.10 \\
\hline 30 Jul 1986 & $14: 53$ & EBES & 29.21 & 29.27 & 0.13 \\
\hline
\end{tabular}

Table 2. Dates, pass times, chorophyll pigment concentration for EBG at pixel $\mathrm{P}$, and mean and standard deviation for $3 \times 3$ pixel matrix centered at $\mathrm{P}$ for Nimbus 7 CZCS satellite images

\begin{tabular}{|ccccc|}
\hline \multicolumn{1}{l|}{ Date } & Time $(\mathrm{h})$ & $\mathrm{P}$ & \multicolumn{2}{c|}{ Pixel matrix } \\
& & $\left(\mathrm{mg} \mathrm{m}^{-3}\right)$ & Mean $\left(\mathrm{mg} \mathrm{m}^{-3}\right)$ & $\mathrm{SD}\left(\mathrm{mg} \mathrm{m}^{-3}\right)$ \\
\hline 5 May 1981 & $11: 54$ & 0.2194 & 0.2693 & 0.0345 \\
10 May 1981 & $11: 44$ & 0.1741 & 0.1673 & 0.0074 \\
\hline
\end{tabular}

All images were converted to rectangular projections with north upward, eliminating the effect of the earth's curvature and the satellite's tilt angle. The accuracy of temperatures measured with the AVHRR was $\pm 0.3 \mathrm{C}^{\circ}$ (Bernstein 1982). The algorithms used for determining chlorophyll pigment concentrations from CZCS radiometer channels 1 and 4 are discussed by Gordon et al. (1983). The accuracy of measurements by the CZCS was $\pm 30 \%$ of shipboard-measured values (Gordon et al. 1983).

Sea surface temperatures were recorded daily at EBES from 22 to 24 and 26 to 30 July 1986 from NOAA 9 AVHRR images. The pass times ranged from $14: 28 \mathrm{~h}$ on 23 July to 15:57 h on 24 July, a temporal separation of less than 1.5 h. The confounding effect of diurnal warming and nocturnal cooling on between-day differences was, for this reason, minimal. These images were magnified $8 \times$ to facilitate discrimination of local hydrographic changes. A 256 -increment gray scale was assigned to an $8 \mathrm{C}^{\circ}$ range from 25 to $33^{\circ} \mathrm{C}$, resulting in $0.02 \mathrm{C}^{\circ}$ resolution.

AVHRR sea surface temperature measurements were integrated over $1.1 \mathrm{~km}^{2}$, the area resolved by a single pixel on an AVHRR image. The chlorophyll pigment concentration was integrated over $0.8 \mathrm{~km}^{2}$, the area covered by a single pixel on a CZCS image. The temperature and chlorophyll pigment concentration for that pixel (see $P$ values in Tables 1 and 2) were plotted over the time period we observed the change in abundance of assemblage members. Due to the size similarity between the seamount areas and the measurement areas of the satellite image pixels, the former area may have overlapped any of the 8 pixels adjacent to pixel $\mathrm{P}$ If such overlapping were to occur, the P measurements would not represent solely the temperatures and chlorophyll pigment concentrations at the seamounts, but the measurements would be influenced also by those temperatures and chlorophyll concentrations in the surrounding pelagic environment. For this reason, we calculated the mean and standard deviation for a $3 \times 3$ matrix of $P$ and the adjacent 8 pixels for each satellite image. For the AVHRR images, the mean for each matrix of temperature values varied less than $0.1 \mathrm{C}^{\circ}$ from the value recorded at the center pixel $\mathrm{P}$ (Table 1). For the $2 \mathrm{CZCS}$ images, the means from the matrices of chlorophyll pigment concentration values varied more from the center pixel values (Table 2). This variation, particularly high on $5 \mathrm{May}$, resulted from EBG lying on an oceanographic front between inshore (northern) pixels with higher pigment values and offshore (southern) pixels with lower values. 


\section{RESULTS}

\section{El Bajo Gorda Seamount (EBG)}

While few assemblage members were present at EBG on 6 and 7 May, most were present 7 d later on 13 and 14 May (Table 3). Earlier only 3 individuals of Sphyrna lewini and a medium-size school of Seriola rivoliana were censused. However, on 13 and 14 May we recorded 13 oceanic species, and the 2 species observed during our earlier visit were present in large schools.

Although the sea surface temperature at EBG changed substantially from $18.2^{\circ} \mathrm{C}$ on 7 May to $20.0^{\circ} \mathrm{C}$ on 12 May, $1 \mathrm{~d}$ prior to our second visit, the phytoplankton pigment concentration only changed from $0.22 \mathrm{mg} \mathrm{m}^{-3}$ on $5 \mathrm{May}$, a day prior to our initial visit, to 0.17 on 10 May, 3 d prior to our return (Fig. 2). The water mass change is more evident in satellite images of sea surface temperatures and chlorophyll pigment concentrations before and after the assemblage's appearance at EBG (Fig. 3). On 5 May EBG was covered by a band of $\operatorname{cool}\left(19^{\circ} \mathrm{C}\right)$ water lying along the tip of the Baja Peninsula and extending southeastward at the middle of the tip (see direction change of green band at $23^{\circ} 00^{\prime} \mathrm{N}, 109^{\circ} 30^{\prime} \mathrm{W}$ in Fig. 3A) before curving eastward. EBG was on the edge of a triangular area of phytoplankton pigment concentrations ranging from 0.6 to $0.7 \mathrm{mg} \mathrm{m}^{-3}$ (light blue triangle centered at $22^{\circ} 55^{\prime} \mathrm{N}, 109^{\circ} 40^{\prime} \mathrm{W}$ with a base along the peninsula tip and apex southeastward; Fig. 3C). A wedge of cool, plankton-rich water is usually present off the tip of the peninsula from October to April (Wyrtki 1966). The abundance of plankton at this time is linked to local upwelling of nutrient-rich water in response to strong northerly winds (see records of U.S. Navy 1977). By late

Table 3 . Species present $(+)$ or absent $(-)$ at El Bajo Gorda during cruise visit on 6 and 7 May and day trips on 13 and 14 May 1981

\begin{tabular}{|c|c|c|c|c|}
\hline \multirow[t]{2}{*}{ Species } & \multicolumn{4}{|c|}{ May } \\
\hline & 6 & 7 & 13 & 14 \\
\hline Alopias sp. & - & - & + & - \\
\hline Caranx caballus & - & - & + & + \\
\hline Caranx hippos & - & - & + & + \\
\hline Carcharhinus falciformis & - & - & + & - \\
\hline Carcharhinus limbatus & - & - & + & + \\
\hline Lutjanus aratus & - & - & + & + \\
\hline Lutjanus peru & - & - & + & + \\
\hline Manta hamiltoni & - & - & - & + \\
\hline Rhincodon typus & - & - & - & + \\
\hline Seriola lalandi & - & - & - & + \\
\hline Seriola rivoliana & - & + & + & + \\
\hline Sphyma lewini & - & + & + & + \\
\hline Trachinotus rhodopus & - & - & + & + \\
\hline
\end{tabular}

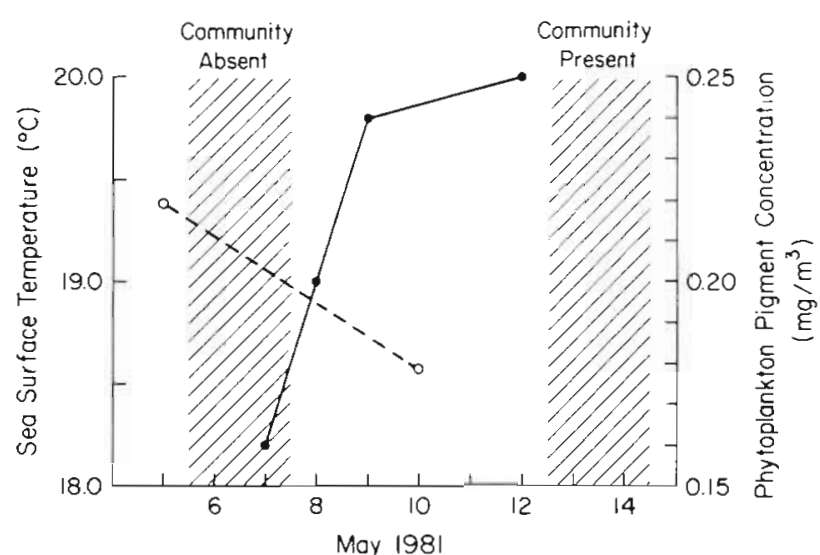

Fig. 2. NOAA 6 AVHRR sea surface temperatures (solid line) and Nimbus 7 CZCS phytoplankton pigment concentrations (dashed line) recorded at image pixel corresponding to the location of $\mathrm{EBG}$ at times proximate to those when the assemblage was censused by free and SCUBA diving (hatched). Note cloud cover during the latter census period precluded our obtaining temperature and pigment measurements at that time

April the direction of prevailing winds shifts to the southeast. Such a change occurred between our visits to EGB. By 12 May the band of cooler water was northeast of EBG. The large front south of the peninsula was now further west, aligned with the western coast of the peninsula. Water temperatures surrounding EBG averaged $20^{\circ} \mathrm{C}$. The large triangular area of cool temperatures south of the Baja Peninsula (green and blue triangle with apex at $22^{\circ} 30^{\prime} \mathrm{W}, 107^{\circ} 15^{\prime} \mathrm{N}$ ) was due to cloud cover. Pigment concentrations surrounding EBG now averaged $<0.2 \mathrm{mg} \mathrm{m}^{-3}$ (dark blue in Fig. 3D).

The change in water mass properties observed at EBG could have been caused either by the cessation of local upwelling or the incursion of a water mass originating south of the Gulf of California. It is impossible to ascertain which process occurred solely on the basis of single pairs of satellite images before and after the appearance of the assemblage. For this reason, we sought to relate a sequence of movements of a member of this assemblage to water mass changes using a concurrent series of satellite images. Furthermore, we wanted to record the presence of this assemblage member at a seamount in a manner not biased by water clarity.

\section{El Bajo Espiritu Santo Seamount (EBES)}

Scalloped hammerhead sharks exhibited 2 distinct departure and arrival patterns at EBES. Firstly, individuals left at dusk, moved distances up to $20 \mathrm{~km}$ into the surrounding pelagic environment at night, and returned to EBES at dawn on the following day (Klimley \& Nelson 1984, Klimley et al. in press). Secondly, groups 

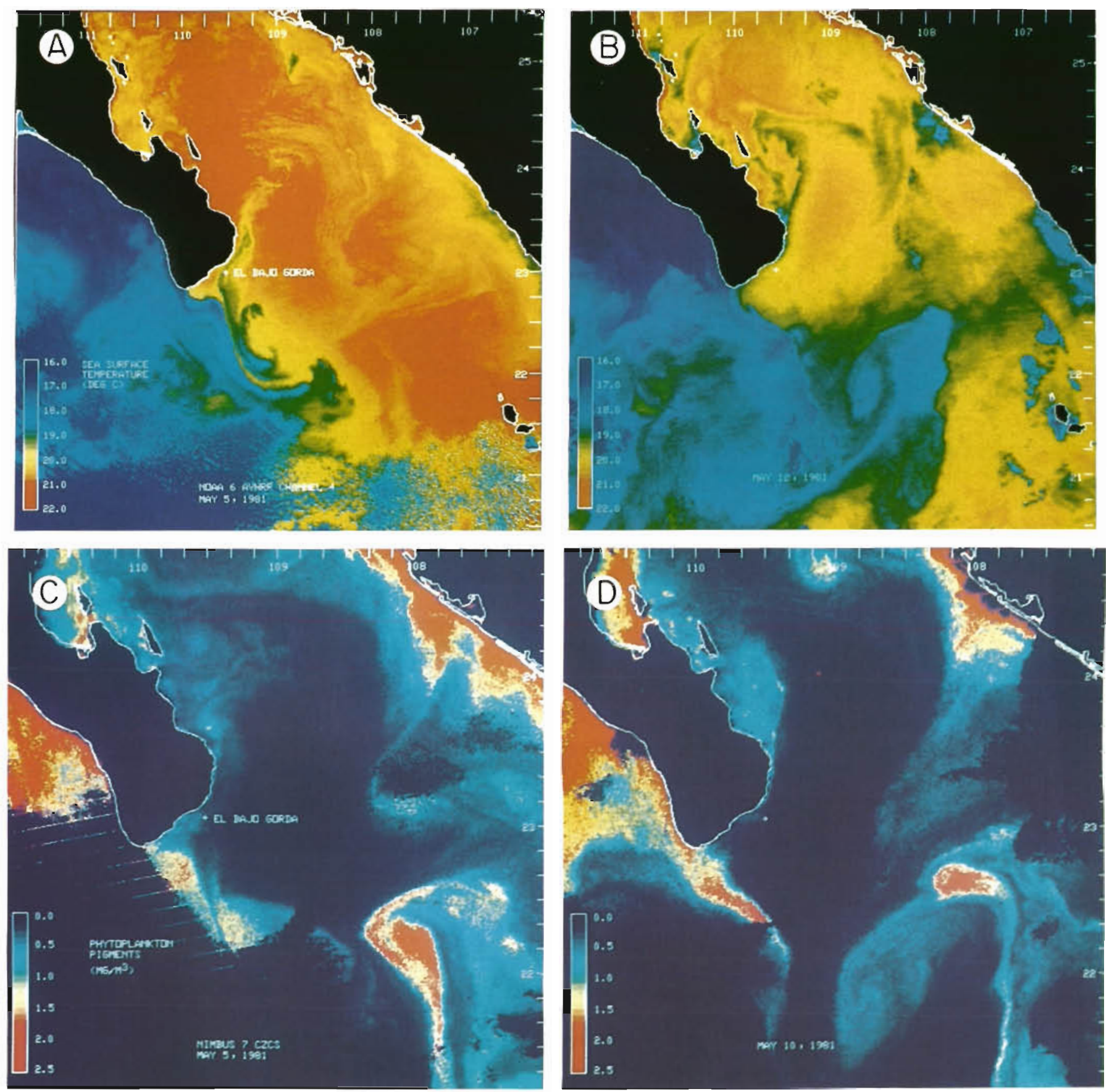

Fig. 3. NOAA 6 AVHRR images of sea surface temperatures at seamount EBG (denoted by white cross) on (A) 5 and (B) 12 May. Nimbus 7 CZCS images of phytoplankton pigment concentrations on (C) 5 and (D) 10 May

of sharks left EBES during daytime and remained away for a few days before returning. We believe these emigrations and immigrations were in response to changes in the properties of the local water masses.

Although daily return rates from hammerheads tagged at EBES remained above $50 \%$ from 23 to 25 July, the rates diminished during the next $3 \mathrm{~d}$ to $17 \%$ (Fig. 4). Two separate groups left on 24 and 25 July (note departures in 2 sets of attached boxes in Table 4). The sea surface temperature decreased from $29.1^{\circ} \mathrm{C}$ on 23 July to $26.9^{\circ} \mathrm{C}$ on 26 July (Fig. 4). We believe that these emigrations occurred in response to cool, upwelled, coastal water displacing warm oceanic water at EBES. Coincident with a peak in the local sea surface temperature of $30.6{ }^{\circ} \mathrm{C}$ on 29 July was the return of $67 \%$ of the tagged scalloped hammerheads. These 


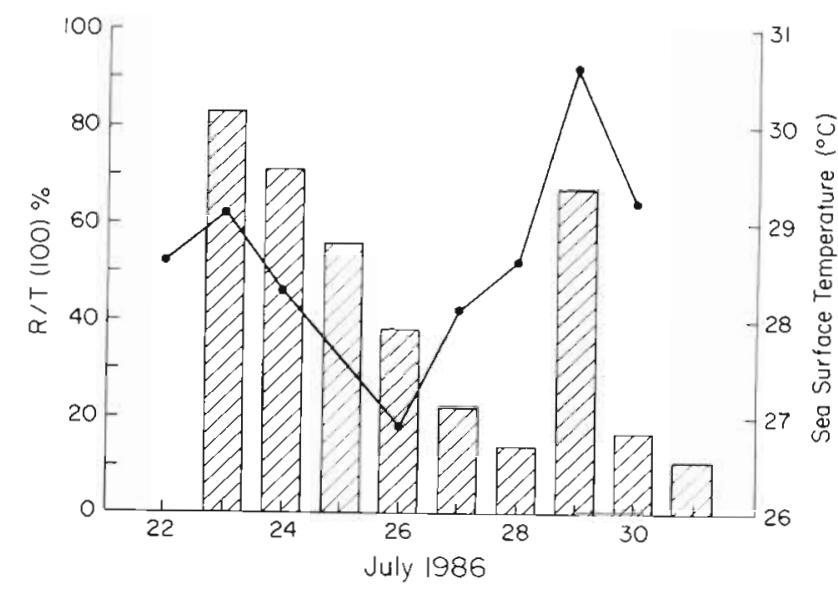

Fig. 4. Return percentages (hatched bars) at EBES of sharks tagged with coded pingers and local sea surface temperatures (solid line) from NOAA 9 AVHRR from 22 to 31 July 1986. Note that the percentage of returns: (1) decreased as temperatures dropped from 22 to $28 \mathrm{July},(2)$ increased coincident with a temperature rise on 29 July, and (3) decreased as the temperature dropped on the next day

sharks arrived within 2 groups (sets of 4 and 5 returns in attached boxes in Table 4). This immigration may have occurred in response to the temporary displacement of the cool local upwelled water with warm oceanic water. When the temperature again dropped to $29.2^{\circ} \mathrm{C}$ on the following day as this warm water mass cooled, only $17 \%$ of the sharks returned (Fig. 4). The increase in returns between 28 and 29 July and the decrease between 29 and 30 July were both statistically significant (Fisher's Exact Probability Test, $p=0.003$ ).
The water mass changes throughout this period can be better understood by viewing satellite images of local sea surface temperatures (Fig. 5). Warm water remained over EBES from 22 to 26 July. This water mass was particularly well defined on 23 July (dark gray area extending from Isla San Jose southeastward across EBES in Fig. 5B). Cold water, originating on 26 July in La Paz Bay (light area within bay in Fig. 5D), moved eastward around the northern side of Isla Espiritu Santo so that that the southeastern boundary of the mass was at EBES on 27 July (light gray in Fig. 6A). On 28 July this cool water mass covered EBES (Fig. 6B). At this time the shark return percentage dropped to a minimum of $17 \%$ (Fig. 4), but $67 \%$ of the sharks returned on the following day when a warm water mass was present at EBES (dark gray extending southeastward from Isla San Jose in Fig. 6C). Returns diminished on the next day when this water mass began to fragment (mottled light gray area near EBES in Fig. 6D). Although the monitors recorded the occurrence of more tagged hammerheads at EBES in the presence of warmer water, a similar immigration pattern for other assemblage members was observed by free divers.

\section{DISCUSSION}

The hammerhead sharks appeared at EBES in the presence of local upwelling. However, the fish assemblage either may have aggregated at EBG from a dispersed distribution in the surrounding pelagic environment, or migrated to EBG within a water mass

Table 4. Sphyrna lewini. Returns of 18 scalloped hammerhead sharks tagged with individually coded transmitters over $10 \mathrm{~d}$ period from 2 microprocessor-based monitors placed at 3 sites at EBES. R: returning tagged sharks; $\mathrm{T}$ : tagging of sharks. $\mathrm{R} / \mathrm{T}(100) \%=$ percentage of tagged sharks returning. Squares connected on undersides are grouped daytime (07:00 $<t<18: 00 \mathrm{~h})$ departures separated by $\leq 15 \mathrm{~min}$; squares connected on topsides are grouped daytime arrivals separated by $\leq 15 \mathrm{~min}$

\begin{tabular}{|c|c|c|c|c|c|c|c|c|c|c|c|c|c|c|c|c|c|c|c|c|c|}
\hline \multirow[b]{2}{*}{ Date } & \multicolumn{18}{|c|}{ Shark identifications } & \multirow{2}{*}{$\begin{array}{l}\text { Ret. } \\
\text { (R) }\end{array}$} & \multirow{2}{*}{$\begin{array}{l}\text { Tag. } \\
\text { (T) }\end{array}$} & \multirow{2}{*}{$\begin{array}{l}\text { Ret. perc. } \\
\text { RT }(100) \%\end{array}$} \\
\hline & 1 & 2 & 3 & 4 & 5 & 6 & 7 & 8 & 9 & 10 & 11 & 12 & 13 & 14 & 15 & 16 & 17 & 18 & & & \\
\hline 22 July & $T$ & $\top$ & $T$ & $T$ & $\mathrm{~T}$ & & & & & & & & & & & & & & & & \\
\hline 23 July & & R & $R$ & $\mathrm{R}$ & $R$ & T & $T$ & $\mathrm{~T}$ & $T$ & $\mathrm{~T}$ & T & $\mathrm{T}$ & $T$ & $T$ & & & & & 4 & 5 & 80 \\
\hline 24 July & & & \begin{tabular}{|l|l}
$R$ \\
\end{tabular} & & 8 & $\mathrm{R}$ & $\mathrm{R}$ & 8 & \begin{tabular}{|l}
$\mathrm{R}$ \\
\end{tabular} & $R$ & & $\mathrm{R}$ & $\frac{R}{1}$ & 8 & $T$ & \begin{tabular}{|l|}
$T$ \\
\end{tabular} & & & 10 & 14 & 71 \\
\hline 25 July & & & R & & 8 & & $\mathrm{R}$ & $R$ & R & $R$ & & $R$ & & $\mathrm{R}$ & & 8 & & & 9 & 16 & 56 \\
\hline 26 July & & & R & $R$ & $R$ & & & & & & $\mathrm{R}$ & & & & $\mathrm{R}$ & R & $T$ & $\mathrm{~T}$ & 6 & 16 & 38 \\
\hline 27 July & & & $R$ & & R & $R$ & $\mathrm{R}$ & & & & & & & & & & & & 4 & 18 & 22 \\
\hline 28 July & & & & & $R$ & R & $R$ & & & & & & & & & & & & 3 & 18 & 17 \\
\hline 29 July & A & $R$ & $\mathrm{R}$ & A & $\mathrm{R}$ & $R$ & $R$ & \begin{tabular}{|l}
$R$ \\
\end{tabular} & $R$ & 9 & \begin{tabular}{|l|} 
\\
\end{tabular} & & & & $\mathrm{R}$ & & & & $\{2$ & 18 & 67 \\
\hline 30 July & & & & & & $R$ & $R$ & & & & & & & & & & $R$ & & 3 & 18 & 17 \\
\hline 31 Juily & & & & & & $R$ & & & & & & & & & & & $\mathrm{R}$ & & 2 & 18 & 11 \\
\hline
\end{tabular}



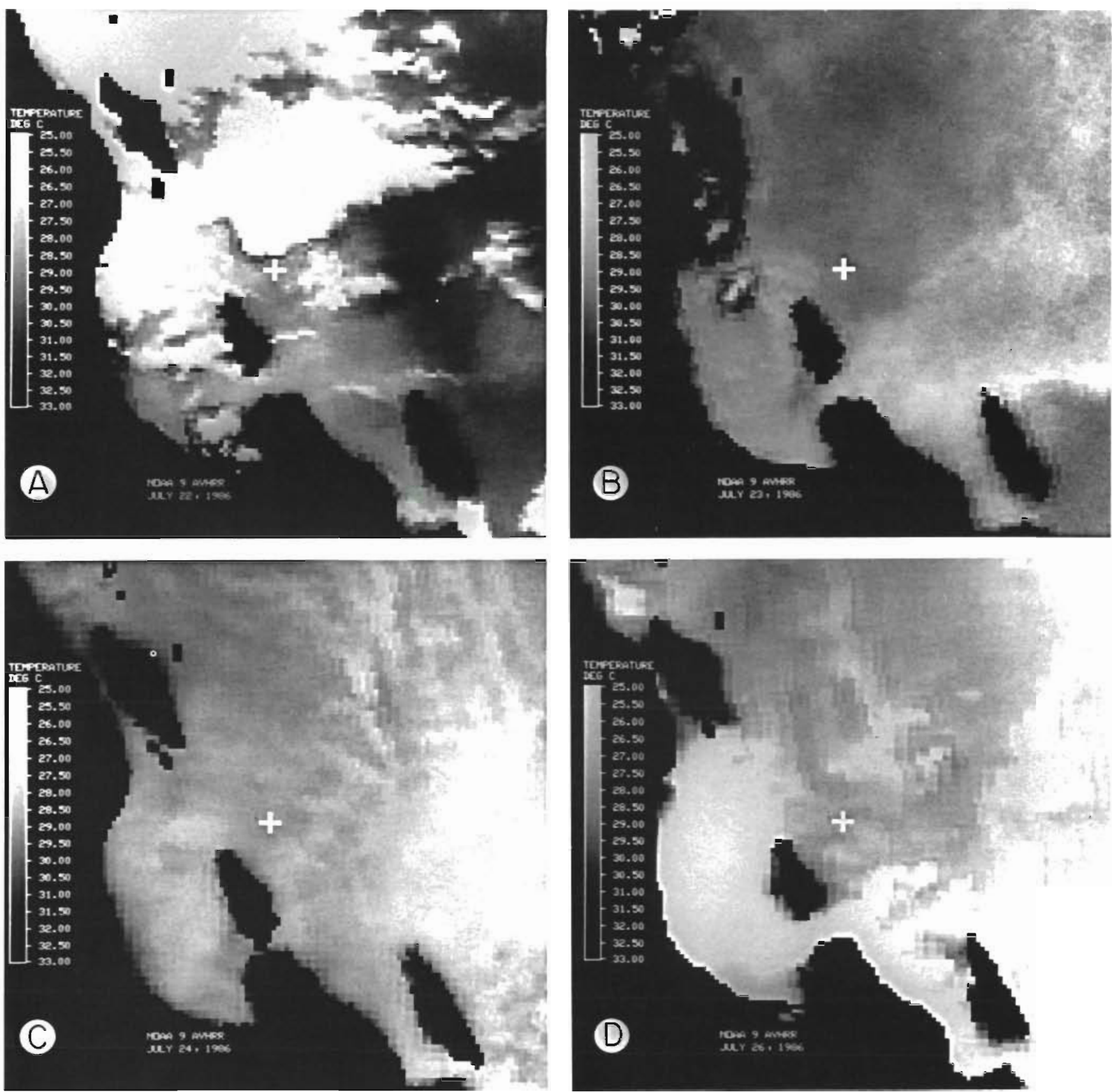

Fig. 5. NOAA 9 AVHRR sea surface temperature images of La Paz Bay area (Fig. 1), centered at EBES (designated by white cross) (A to C) 22 to 24 July; (D) 26 July 1986. Warm water remained over EBES through 25 July. On the next day upwelling of cool water occurred in La Paz Bay (light color within the bay in D)

originating south of the Gulf of California off Mazatlan. Supporting the former hypothesis are occasional records of the scalloped hammerhead, an assemblage member, at EBG during winter (Klimley 1982). However, more evidence favors the latter hypothesis. Firstly, assemblage members were not observed during fall, winter, and early spring cruises to EBG but were recorded during the summer cruise (Table 5). Assem- blage members were not recorded during fall, winter, and spring cruises to 6 other locations along a $280 \mathrm{~km}$ latitudinal gradient northward along the Baja Peninsula, but were observed at EBG and 3 of these locations during the summer cruise (Klimley unpubl.). Secondly, the scalloped hammerhead and Carcharhinus falciformis, both assemblage members, are not captured by the fishery off Isla Cerralvo (Fig. 1) during autumn and 

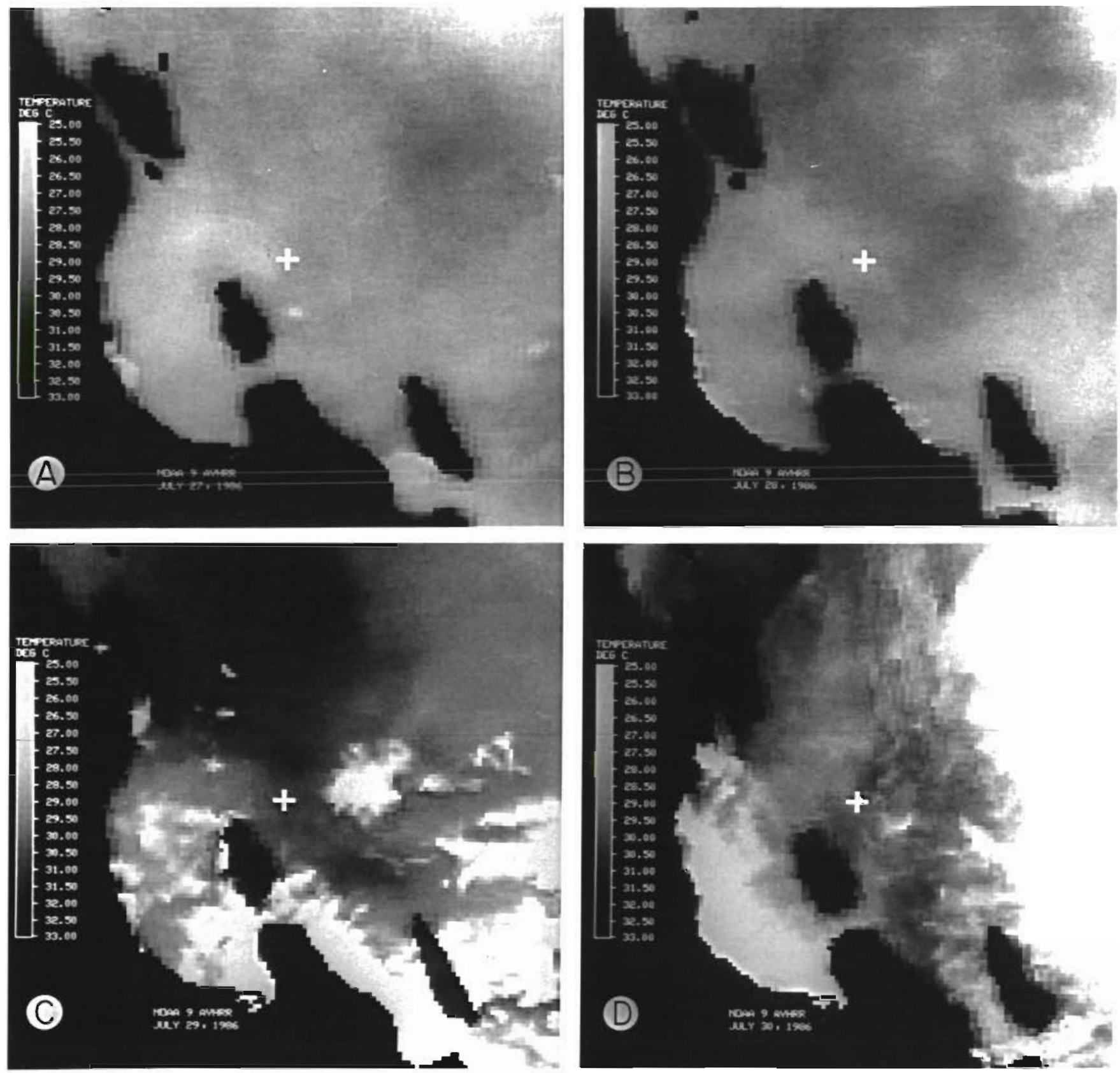

Fig. 6. Sea surface temperature images from 27 to 30 July 1986. Cold water moved out of La Paz Bay to cover EBES on 28 July (light gray extending from the Bay around Isla Espiritu Santo in A and B). Warm water covered EBES on 29 July (dark gray extending southeastward from Isla San Jose in C). Cool water returned on 30 July (mottled gray near EBES in D)

winter (Calvan-Magana et al. unpubl.). However, the scalloped hammerhead and another assemblage member, Carcharhinus limbatus, are caught in winter south of the Gulf of California off the southwestern coast of Mexico by fishermen based at Mazatlan (Carvallo 1967, Kato \& Carvallo 1967). Thirdly, water temperatures near Mazatlan remain considerably higher throughout winter than in the Gulf of California (see temperature contour maps in Robinson 1973).

The warmer water with a lower chlorophyll concen- tration present at EBG on 13 and 14 May may have originated off Mazatlan southeast of the Gulf of California. In both CZCS images a water mass, identified from chlorophyll pigment concentrations higher than in the surrounding water, was centered at $22^{\circ} 10^{\circ} \mathrm{W}$, $107^{\circ} 50^{\prime} \mathrm{N}$, southeast of the peninsula. A projection from this mass, extending eastward (red, yellow, and white, crescent-shaped area between $22^{\circ} 20^{\prime} \mathrm{W}, 108^{\circ} 20^{\prime} \mathrm{N}$ and $22^{\circ} 00^{\prime} \mathrm{W}, 107^{\circ} 10^{\prime} \mathrm{N}$ in Fig. $3 \mathrm{C}$ ), may have moved in a northeastern direction. A second projection (light blue 
Table 5. Species present $(+)$ or absent $(-)$ in censuses carried out during seasonal cruises to El Bajo Gorda on: (F) 8-9 Nov, (W) 31 Jan to 2 Feb, (Sp) 6-7 May, and (Su) 10-13 Aug, 1980-81. Species were observed while SCUBA diving or free diving during repeated drifts over the study site

\begin{tabular}{|lcccc|}
\hline Species & \multicolumn{5}{c|}{ Cruise censuses } \\
& F & W & Sp & Su \\
\hline Acanthocybium solanderi & + & - & - & + \\
Alopias sp. & - & - & - & - \\
Caranx caballus & - & - & - & + \\
Caranx hippos & - & - & - & + \\
Carcharhinus falciformis & - & - & - & + \\
Carcharhinus limbatus & - & - & - & + \\
Lutjanus aratus & - & - & - & + \\
Lutjanus peru & - & - & - & + \\
Makaira nigricans & + & - & - & + \\
Manta hamiltoni & - & - & - & + \\
Rhincodon typus & - & - & - & + \\
Seriola lalandi & - & - & - & + \\
Seriola rivoliana & - & - & + & - \\
Sphyma lewini & - & - & + & + \\
Trachinotus rhodopus & - & - & - & + \\
\hline
\end{tabular}

area from $22^{\circ} 40^{\prime} \mathrm{W}, 108^{\circ} 20^{\prime} \mathrm{N}$ to $21^{\circ} 20^{\prime} \mathrm{W}, 108^{\circ} 50^{\prime} \mathrm{N}$ in Fig. 3D) may have extended southwestward. Southeasterly winds would push such a mass of warm water into the Gulf and force the wedge of cooler coastal water at the peninsula tip westward. This warm water mass would also compress the water mass along the southeastern coast north of the peninsula tip (light blue area centered at $23^{\circ} 50^{\prime} \mathrm{W}, 109^{\circ} 30^{\prime} \mathrm{N}$ in Fig. 3D), increasing chlorophyll pigment concentrations within that mass from $0.5 \mathrm{mg} \mathrm{m}^{-3}$ to $0.8 \mathrm{mg} \mathrm{m}^{-3}$.

A change in water circulation of the East Pacific in May is evident in the monthly charts of Wrytki (1965). From late fall to early spring the surface currents flow toward the Gulf of Tehuantepec and then offshore. From late spring to early fall, currents flow northwestward along the mainland past Mazatlan into the Gulf of California. The $24^{\circ} \mathrm{C}$ isotherm moves to within the Gulf after this circulation change. The arrival of this warm water may permit the scalloped hammerhead and other assemblage members to enter the Gulf. Once within the Gulf scalloped hammerhead sharks may remain at a seamount only when it is within a warm oceanic water mass. Hammerhead prey may be abundant near the seamount in the surrounding pelagic environment only at this time. Adult hammerheads feed on pelagic fishes and cephalopods (Klimley 1987).

\section{CONCLUSION}

The appearance between 7 and 13 May 1981 of an assemblage of 18 planktivorous and predatory fishes at EBG in the Gulf of California coincided with an increase in sea surface temperature and chlorophyll concentrations determined from NOAA 6 AVHRR and Nimbus 7 CZCS satellite images, respectively. The appearance of a single species, the scalloped hammerhead, at EBES was later used as an indicator of assemblage movements. Eighteen individuals were tagged with coded pingers and their presence at EBES was detected by 2 locally deployed microprocessor monitors. From 26 to 28 July 1986, the percentage of sharks returning to EBES decreased to $17 \%$ as a mass of cold water, originating in the Bay of La Paz, moved over EBES. Sixty-seven \% of these sharks returned to EBES on 29 July when a warm water mass of oceanic origin displaced the cooler water over EBES. Upon the return of cooler water to EBES on the next day, again only $17 \%$ of the tagged sharks returned to EBES

In both instances, the appearance of the assemblage occurred after water mass changes. In the latter instance, the arrival and departure of the assemblage from EBES was related to local upwelling of cooler water. Although, in the former instance, the species may have aggregated at EBG from the adjacent pelagic environment in response to local upwelling, we believe it more likely that the assemblage immigrated to EBG within a water mass originating off Mazatlan south of the Gulf of California. The late fall to early spring current flow southeastward toward the Gulf of Tehuantepec reverses at this time to the late spring to early fall northeastward flow along the mainland into the Gulf.

Acknowledgements. We especially thank C. H. Gautier of the California Space Institute. The first part of this study grew out of an assignment to S. B. Butler in her satellite imagery course at Scripps Institution of Oceanography. We also acknowledge the help of Jan Svejkovsky in our choice of image processing algorithms. We further express our appreciation to the members of the United States-Mexican scientific party who participated on the July and August 1986 cruise during which we obtained data on the distribution of scalloped hammerheads at EBES. These investigators were I. Cabrera, P. Gonzales, H. Kent, K. Milligan, M. Ross, and V. Welch. The manuscript was improved by the editorial comments of M. R. Abbott, N. Christensen, O. Holm-Hansen, R. M. Laurs, C. D. Winant, R. $H$. Rosenblatt, and an anonymous reviewer. Support for this research was obtained from the Biological Oceanography and Psychobiology Programs of the National Science Foundation through grants BNS 84-19076 and BNS 87-08304.

\section{LITERATURE CITED}

Bernstein, R. L. (1982). Sea surface temperature estimation using the NOAA 6 satellite Advanced Very High Resolution Radiometer. J. geophys. Res. 87: 9455-9465

Carvallo, A. H. (1967). Observations on the hammerhead sharks (Sphyrna) in waters near Mazatlan, Sinaloa, Mexico. In: Gilbert, P. W., Mathewson, R. R., Rall, D. P. (eds.) Sharks, skates, and rays. Johns Hopkins Press, Baltimore, p. 79-92 
Fisher, R. L., Rustnak, G. A., Shepard, F. P. (1964). Chart I: Submarine topography of the Gulf of California. Am. Ass Pet. Geol. Mem.: Insert

Gordon, H. R., Clark, D. K., Brown, J W., Evans, R. H., Broenkow, W W. (1983). Phytoplankton pigment concentrations in the Middle Atlantic Bight; comparison of ship determinations and CZCS estimates. Appl. Optics 22: $20-37$

Kato, S., Carvallo, A. H. (1967). Shark tagging in the Eastern Pacific Ocean, 1962-65. In: Gilbert, P. W., Mathewson, R. F., Rall, D. P. (eds.) Sharks, skates, and rays. Johns Hopkins Press, Baltimore, p. 92-109

Klimley, A. P. (1982). Social organization of schools of scalloped hammerhead shark, Sphyma lewini (Griffith and Smith), in the Gulf of California. Dissertation, Univ. Califormia, San Diego

Klimley, A. P. (1987). The determinants of sexual segregation in the scalloped hammerhead shark, Sphyrna lewini. Environ. Biol. Fish. 18: 27-40

Klimley, A. P., Butler, S. B., Nelson, D. R., Stull, A. T (in press). Diurnal movements of scalloped hammerhead sharks ((Sphyrna lewini Griffith and Smith) to and from El Bajo Espiritu Santo in the Gulf of Calıfornia. J. Fish. Biol.
Klimley, A. P, Nelson, D. R. (1984). Diel movement patterns of the scalloped hammerhead shark (Sphyrna lewini) in relation to El Bajo Espiritu Santo: a refuging central-position social system. Behav. Ecol. Sociobiol. 15: 45-54

Laurs, R. M., Fiedler, P. C., Montgomery, D. R. (1984). Albacore than catch distributions relative to environmental features observed from satellites. Deep Sea Res. 31 1085-1099

Laurs, R. M., Yuen, H. S. H., Johnson, J. H. (1977). Small-scale movements of albacore, Thunnus alalunga, in relation to ocean features as indicated by ultrasonic tracking and oceanographic sampling. Fish. Bull. U. S. 75: 347-355

Robinson, M. K. (1973). Atlas of monthly mean sea surface and subsurface temperatures in the Gulf of California. San Diego Soc. nat. Hist. Mem. 5: 1-19

U.S. Navy (1977). Marine climatic atlas of the world, Vol. II, North Pacific Ocean. U.S. Government Printing Office, Washington D. C.

Wyrtki, K. (1965). Surface currents of the eastern tropical Pacific Ocean. Bull. inter-Am. trop. Tuna Commn 9. 271-304

Wyrtki, K. (1965). Surface currents of the eastern tropical Pacific Ocean. Oceanogr. mar. Biol. A. Rev. 4: 33-68

This article was presented by Dr O. Holm-Hansen it was accepted for printing on June 7, 1988 